\title{
Sever Hastalığı: Çocuklarda Topuk Ağrısının Önemli Bir Nedeni; Olgu Sunumu
}

\author{
Sever Disease: An Important Cause of Heel Pain in Children; Case Report \\ Yavuz Ali Karahan, Ender Salbaş*, Levent Tekin, Ozan Yaşar**, Adem Küçük*** \\ Beyhekim Devlet Hastanesi, Fiziksel Tip ve Rehabilitasyon Kliniği, Konya, Türkiye \\ ${ }^{*}$ Ağrı Devlet Hastanesi, Fiziksel Tıp ve Rehabilitasyon Kliniği, Ağrı, Türkiye \\ **Amasya Üniversitesi Tıp Fakültesi, Sabuncuoğlu Şerefeddin Devlet Hastanesi, Fiziksel Tıp ve Rehabilitasyon Kliniği, Amasya, Türkiye \\ ***Necmettin Erbakan Üniversitesi Tıp Fakültesi, Romatoloji Bilim Dalı, Konya, Türkiye
}

\section{Özet}

Çocuklardaki topuk ağrııının en sık nedeni kalkaneal apofizittir ve Sever hastalığı olarak tanımlanmışıı. Tipik olarak hızlı büyüme evresindeki çocuklarda ve egzersiz sezonunun başlangıında görülür. Sadece çocuklardaki topuk ağrısı ile ilişkilidir ve puberteden sonraki dönemde görülmez. Topuk ağrısı ile başvuran bir çocuk hastada ayırıcı tanıda aşil tendiniti, retrokalkaneal bursit, kalkaneal stres kırığı, kalkaneal kistler, osteomiyelit ve plantar fasiit göz önünde bulundurulmalıdır. İyi bir klinik değerlendirme ile ayırıcı tanıda yer alan diğer nedenler Sever hastalığından ayrılır. Sık karşılaşılan bir klinik tablo olmasına rağmen Sever hastalığı hakkında ulusal ve uluslararası literatürde oldukça az dokümantasyon bulunmaktadır. Yazımızda bilateral topuk ağrısı ve aksayarak yürüme şikayetleri ile başvuran 12 yaşındaki erkek hasta eşliğinde, hastalığın, belirti ve bulgularını, tanısal yaklaşımlarını ve tedavi protokollerini güncel literatürler eşliğinde sunmayı amaçladık. (Türk Osteoporoz Dergisi 2014;20: 86-8)

Anahtar kelimeler: Çocuk, Sever hastalığı, topuk ağrısı

\section{Summary}

Calcaneal apophysitis is the most common cause of heel pain in children and described as "Sever disease". Sever disease typically occurs during a growth spurt and at the beginning of a new sport season. The disease is associated with only the heel pain in children and does not occur after puberty. In a child presenting with heel pain, the differential diagnosis may include achilles tendonitis, retrocalcaneal bursitis, calcaneal stress fractures, calcaneal cysts, osteomyelitis, and plantar fasciitis. Other reasons included in the differential diagnosis can be ruled out with a well-performed clinical evaluation. Although Sever disease is a common clinical entity there are quite a few documentations about this disease in national and international literature. In this article we aimed to present a 12-year-old male patient who presented with complaints of bilateral heel pain and limping, and to evaluate signs and symptoms, diagnostic approaches and treatment protocols of the disease in the light of current literature. (Turkish Journal of Osteoporosis 2014;20: 86-8)

Key words: Children, Sever's disease, heel pain

\section{Giriş}

Çocuklarda en sık topuk ağrısı nedeni kalkaneal apofizittir ve tipik olarak hızlı büyüme döneminde ya da spor sezonunun başında ortaya çıkar (1). Hastalık ilk kez hastalığa adını veren Sever tarafından 1912 yılında tanımlanmıştır. Sever topuğun ağııı durumunu çocuk hastalarda tanımlamış ve asla puberteden sonra olmayacağını bildirmiştir (1). Hastalık genel olarak bir aşırı kullanım sendromudur (2). Osgood-Schlatter hastalığının analoğudur ve inflamatuvar bir süreç olarak tanımlanmaktadır (2). Yaşı 20'nin altındaki tüm atletlerde \%5,8' lik insidansa sahiptir. Sever Hastalığı (SH) futbol gibi koşma atlama aktivitelerinin yapıldığı sporlarla ilişkilidir ve bu gibi aktivitelere devam etmek semptomları alevlendirmektedir $(2,3)$.

Büyüme çağındaki çocukların topuk ağrılarının en sık sorumlusu olan SH'nin ortalama görülme yaşı 11'dir ve 8 ile 15 yaş arasında bir dağılım sergilemektedir. Genç futbol oyuncularına ait yaralanmalar incelendiğinde hastalığın hızlı pubertal büyüme döneminde en sık olduğu, erkek-kız oranının 2-3:1 olduğu ve her iki topukta görülme insidansının yaklaşık olarak \%60 olduğu görülmektedir $(2,3)$. Hastalığa ait tipik vaka kronik topuk ağrısından yakınan pre-adölesandır. Ağrı aktivite ile artmaktadır. Kalkaneal kısmın arkasının medialden laterale kadar

Yazışma Adresi/Address for Correspondence: Dr. Yavuz Ali Karahan, Beyhekim Devlet Hastanesi, Fiziksel Tip ve Rehabilitasyon Kliniği, Konya, Türkiye Tel.: +90 3322337142 E-posta: ayk222@hotmail.com Geliş Tarihi/Received: 07.05.2014 Kabul Tarihi/Accepted: 26.05.2014

Bu yazının özeti 2-5 Nisan 2014 tarihinde düzenlenen "World Congress on Osteoporosis, Osteoarthritis and Musculoskelatal Diseases, Seville, Spain" kongresinde poster olarak sunulmuştur. 
olan bölümünün kompresyonu ile ortaya çıkan ağrı dışında muayenede herhangi bir anormallik yoktur $(2,3)$. Parmak ucu yürüyüşü ile ağrı genellikle rahatlama eğiliminde olduğundan hasta dorsofleksiyonu hafifçe azaltmış olarak yürür. Tanı klinik muayene ile konabilir $(1,3)$.

Kendini sınırlayan bir hastalık olan SH'ye ait çok fazla dokümante veri yoktur. Üç aydır topuk ağrısı olan 12 yaşındaki bu olgu ile hastalığa ait klinik özelliklere ışık tutulmuş olunacaktır.

\section{Olgu}

Fizik Tedavi ve Rehabilitasyon Polikliniği'ne başvuran 12 yaşındaki erkek hastanın aşil tendonunun topuğa yapıştığı bölgede, aktiviteyle artan, 3 aydır olan ağrısı vardı. Hasta ağrısının oturduğu yerden ya da sabahları yataktan kalkarken daha çok olduğunu, bu durumun son 2 haftadır arttığını ve ağrıyı azaltmak için parmak uçlarına basarak yürüdüğünü ifade ediyordu. Ağrının başlamasına neden olan travma öyküsü yoktu. Aktiviteyle artıp istirahatle artan ağrısı künt karakterdeydi ve yayılım göstermiyordu. Hikayesinde kilo kaybı, ateş, alerji, kronik hastalık, hastanede yatış, cerrahi operasyon öyküsü yoktu. Aile fertlerinde benzer hastalık öyküsü olan yoktu. Fizik muayenede inspeksiyon bulgusu olarak hasta iyi beslenmiş, solgun olmayan normal cilt görünümündeydi ve vital bulguları normaldi. Aksayarak yürüyen hastanın fizik muayenesinde her iki kalkaneus posteriorunda hassasiyet mevcuttu. Ayrıca her iki subtalar ekleme ait hareket açıklığı dorsofleksiyon, plantar fleksiyon inversiyon ve eversiyon yönlerinde azalmıştı. Thompson testinde aşil tendonun normal olduğu görüldü. Hastadan tam kan, eritrosit sedimantasyon hızı, alkalen fosfataz, serum kalsiyum seviyesi istendi ve normal aralıkta oldukları görüldü. Hastadan istenen Romatoid faktör de negatifti. Hastanın lateral ayak bileği grafisinde kalkaneal apofizin fragmante ve skleroze olduğu görüldü (Resim 1). Manyetik rezonans görüntüleme ile kalkaneus metafizinde ve apofiziyel alanda kemik zedelenmesi ve mikrofraktürle uyumlu görünüm elde edildi (Resim 2). Mevcut bulgular ile hastaya $\mathrm{SH}$ tanısı konuldu ve yakınmalarını artıran sportif faaliyetlerine son vermesi önerildi. Her iki topuk için silikon topuk yükseltici tabanlık kullanılması sağlandı. Günde 3 kez 400 mg oral ibuprofen ve topuk bölgesine sürmek üzere topikal diklofenak 3 hafta kullanmak üzere reçete edildi. Hastaya germe ve güçlendirme egzersizleri tarif edildi. Toplam yirmi seans iyontoforez sonrası germe ve her 2 topuğa da 15'er dakikalık soğuk uygulama yapıldı.

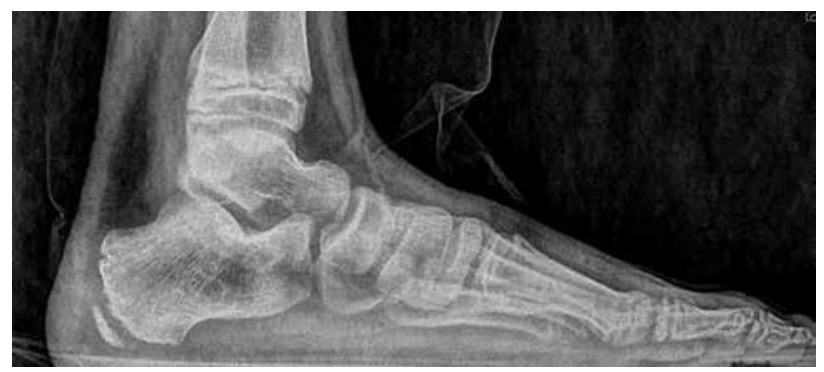

Resim 1. Kalkaneal apofizde direk grafide izlenen skleroz ve fragmantasyon
Her iki subtalar ekleme de manuel germe ve eklem mobilizasyonu uygulandı. Tedavi ile 2 ay içinde yakınmaları düzelen hastanın kontrol muayenesinde topuk bölgesinde palpasyonla hassasiyet yoktu ve eklem hareket açıklığı muayeneleri normaldi. Herhangi bir yürüyüş bozukluğu saptanmadı. Hastanın günlük aktivitelerine geri dönmesine müsade edildi.

\section{Tartışma}

Aşil tendonunun kalakneusa yapıştığı bölgede bulunan kalkaneal apofiz kıkırdak sütunlarından oluşmaktadır ve ossifikasyonun ikincil merkezidir. Apofizit ise tekrarlayan mikrotravmalar neticesinde ortaya çıkar ve kemik-kıkırdak bileşkesinde mikroavulsiyonlara neden olur. Durumun ortaya çıkması için kemiğin iyileşme kapasitesinin üzerinde bir tekrarlayıcı yaralanma olması gerekmektedir $(2,4)$.

SH olan bir çocuk hastanın yakınması kalkaneus posteriorunda, yayılım göstermeyen, topuk üzerine yük binen aktivitelerle artıp istirahatle azalan ağrıdır. Ağrıya genellikle eşlik eden diğer bulgu ise azalmış aşil tendon esnekliğinin neden olduğu ayak bileği dorsofleksiyon kaybıdır. Dorsofleksiyon 10 derece veya daha az olabilir (5). Ağrı zamanla artar ve kişinin fiziksel aktivitelerini yapmasına engel olacak kadar şiddetlenebilir. Büyüme çağındaki çocuklarda, alt ekstremite uzun kemiklerindeki büyüme kas ve tendonların büyümesinden daha hızlı olması nedeniyle ayak bileğinde dorsofleksiyon kaybı olabilmektedir $(3,4)$. Bu büyüme farklılı̆ı, topuğa yük binen aktiviteler sırasında kalkaneal apofiz üzerindeki gerginliğinin artmasına yol açabilmektedir. SH'nin tanısı radyografi ile konmamakla birlikte diğer potansiyel topuk ağrısı nedenlerinin dışlanması için yararlıdır (6).

Topuk yükseltici tedavinin SH'de kullanımı iyi bilinmektedir. Sever topuğa binen yükün ve aşil tendonundaki gerginliğin azaltııması için topuk yükselticilerin kullanılmasını önermektedir $(3,4)$. Topuk yükselticilerin kullanımı SH'nin tedavisinin standart bileşeni olma özelliğini sürdürmektedir. MacLellan ve Vyvyan (7) viskoelastik topuk takviyelerinin topuk vurma sırasında yer tepkime kuvvetini azalttığını ve topuk ağrısını azalttığını bildirmiştir. Ayrıca Madden ve Mellion (8) topuk yükseltici ya da viskoelastik topuk takviyelerinin şok darbesini azalttığı için SH olan kişilerde kullanılmasını önermektedir. Daha dirençli veya şiddetli seyreden olgularda oral nonsteroid anti inflamatuvar ilaçlardan (NSAii) ya da 2-4 hafta boyunca kullanılacak kısa bacak alçılamasından yararlanılabilinir $(6,8)$.

$\mathrm{SH}$ olan kişilerde fizik tedavinin arzu edilen sonucu kişinin tüm fiziksel aktivitelerine dönebilmesidir. Bunun için de

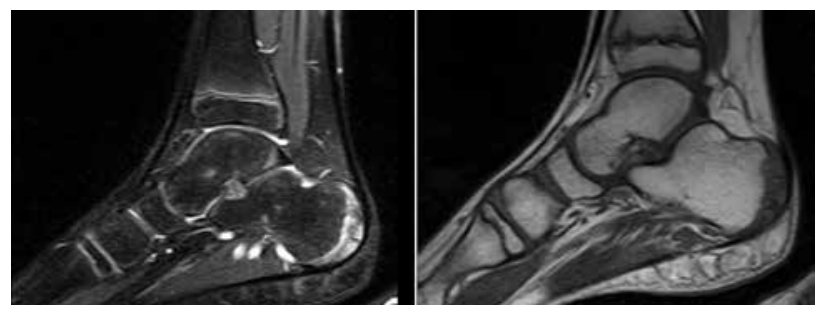

Resim 2. Manyetik rezonans görüntülerde kalkaneus apofizinde ve apofizial bölgede kemikteki hasar ve mikrofraktürler izlenmekte 
hastanın topuğuna yük binmesi sırasında ağrının olmaması gerekmektedir $(7,8)$. Ağrı kontrol altına alındıktan ve kaybolduktan sonra aktivitelere dönüş kademeli olarak başlatılabilir. Kalkaneusun sekonder ossifikasyon merkezi 7-16 yaşlar arasında aktiftir. Apofizde kemikleşme başladıktan sonra hastalığın ortadan kalkması nedeniyle hastalık kendi kendini sınırlamaktadır $(5,6)$. Erkeklerde en sık 10-12 yaşlarda görülen SH kız çocuklarında 8-10 yaş arasında görülmektedir. SH sonucu olarak uzun dönemde gözlenen herhangi bir problem bildirilmemiştir. Ancak SH ağrılı olup aktiviteleri sınırlayabilmektedir $(6,9)$. Hastalığın kendini sınırlayan tabiatı neticesinde prognoz oldukça iyidir ve kişi tüm aktivitelerine geri dönebilmektedir. Artan aktivite yoğunluğu, fiziksel aktivite değişikliği, aşil tendonun uzayabilme kabiliyetinde azalma ya da hızlı büyüme dönemi potansiyel tekrarlayan hasarlanmalara yol açarak hastalığa zemin hazırlamaktadır. Germe, güçlendirme, buz uygulama ve uygun ayakkabı seçimi gibi önleyici tedaviler hastalığın tekrarlamaması veya daha da alevlenmemesi için göz önünde bulundurulmalıdır $(6,9)$.

Topuk ağrısından yakınan bir çocuk hastaya tanı konurken aşil tendiniti, retrokalkaneal bursit, kalkaneal stres kırığı, kalkaneal kistler, osteomiyelit ve plantar fasiit ayırıcı tanıda yer almalıdır $(2,6)$. İyi bir klinik değerlendirme ile bu nedenlerin tümü dışlanabilmektedir $(2,3)$.
SH büyüme çağındaki çocuklarda topuk ağısının sık görülen bir nedenidir. Yazımızda bilateral topuk ağrısı ve aksayarak yürüme şikayetleri ile başvuran 12 yaşındaki erkek hasta eşliğinde, hastalığın, belirti ve bulgularını, tanısal yaklaşımlarını ve tedavi protokollerini sunduk.

\section{Kaynaklar}

1. Sever JW. Apophysitis of the os calcis. New York Medical Journal. 1912;95:1025-29.

2. Abdelgawad A, Naga O. Foot. In: Abdelgawad A, Naga O, editors. A Handbook for Primary Care Physicians, Pediatric Orthopedics. 2014 ed. New York. CN: Springer Science+Business Media; 2014. p. 157-197.

3. Micheli LJ, Ireland ML. Prevention and management of calcaneal apophysitis in children: an overuse syndrome. J Pediatr Orthop. 1987:7:34-8.

4. McKenzie DC, Taunton JE, Clement DB, et al. Calcaneal epiphysitis in adolescent athletes. Can J Appl Sport Sci. 1981;6:123-5.

5. Adirim TA, Cheng TL. Overview of injuries in the young athlete. Sports Med. 2003;33:75-81.

6. Lawrence DA, Rolen MF, Morshed KA, Moukaddam H. MRI of heel pain. AJR Am J Roentgenol 2013;200:845-55.

7. MacLellan GE, Vyvyan B. Management of pain beneath the heel and Achilles tendonitis with visco-elastic heel inserts. $\mathrm{Br} J$ Sports Med. 1981;15:117-21.

8. Madden CC, Mellion MB. Sever's disease and other causes of heel pain in adolescents. Am Fam Physician. 1996;54:1995-2000.

9. Hussain S, Hussain K, Hussain S, Hussain S. Sever's disease: a common cause of paediatric heel pain. BMJ Case Rep. 2013;27:12. 